\title{
Sediment Characteristics of Polachira Wetland in Kollam District, Kerala
}

\author{
Geethu .G ${ }^{1}$, N. P. Suresh Babu ${ }^{2}$, T. Vasudevan Nair ${ }^{3}$ \\ P. G. Department of Zoology, M.G. College, Trivandrum-695004, Kerala
}

\begin{abstract}
Wetlands are unique areas that have characteristics of both land and water, as the name implies. The present investigation was undertaken in the Polachira wetland spread over 600 hectares located in Kollam district, kerala. Sediment samples were collected from five different sampling stations for a period of one year from april 2013 to march 2014.. The sediment samples collected were analyzed for texture analysis, organic carbon and chlorophyll pigment (chlorophyll $a, b$ and $c$ ). Textural analysis revealed that sand was a dominant component (82.33\%) followed by clay (42.64\%) and silt (27.24\%). The month wise data of sediment organic carbon ranged from 73.5mg/g to 9.6mg/g during august 2013 at station III and January 2014 at station IV respectively. The monthly data on Chl.a varied from $0.09 \mathrm{mg} / \mathrm{l}$ during may 2013 at station I to $9.6 \mathrm{mg} / \mathrm{l}$ during June 2013 at station IV. The month wise distribution of Chl.b varied from $6.89 \mathrm{mg} / \mathrm{l}$ to $0.01 \mathrm{mg} / \mathrm{l}$. The higher value was recorded in the month of February at station $V$ and lower value was observed in the month of January at station IV \& V. The higher value of Chl.c $(8.39 \mathrm{mg} / \mathrm{l})$ was recorded in the month of February 2013 at station $V$ and lower value $(0.04 \mathrm{mg} / \mathrm{l})$ was recorded in the month of January 2014 at station 1 . Among the soil constituents sand was the dominant component and organic carbon $(73.5 \mathrm{mg} / \mathrm{g})$ are quite high during the monsoon period.
\end{abstract}

Keywords: Wetland, Sediment, Sediment texture, Organic Carbon, chlorophyll pigments

\section{Introduction}

Each fresh water system has an individual pattern of physical and chemical characteristics largely determined by the climatic, geomorphologic and geochemical conditions prevailing in the drainage basin, distance from ocean and the underlying aquifer and the soil cover (Chapman, 1996). Wetlands are among the most important ecosystems that include specific biotopes (Whigham, 1999). The IUCN defined wetlands very broadly for the purpose of the Ramsar Convention on Wetlands of International Importance (IUCN 1971) as: wetlands are areas of marshes, fen, peat land or water, whether natural or artificial, permanent or temporary, with water that is static or flowing, fresh brackish or salt, including areas of marine water the depth of which at low tide does not exceed six meters.

The present investigation was undertaken in the Polachira wetland ( $8^{0} 50$ ' 26.89"- N latitude, $76^{\circ} 42^{\prime}$ '0.3'longitude). Polachira is a wetland spread over 600 hectares located in Kollam district, kerala. As a result of the biodiversity of fish and mussels, Polachira is a favourite destination of migratory birds. The wetland formed in the estuaries of the Ithikkara River and Paravur backwaters is encircled by small rivulets and is thickly vegetated. Five different sampling stations of Polachira wetland were selected. No solid information is available on the sedimentology of Polachira wetland. Hence the present work is a modest attempt at assessing the sediment characteristics of Polachira wetland to conserve the wetland for future generations.

Sediments in general are rich in nutrients (Pandit, 2003). Sediment is the loose sand, clay, silt and other soil particles that settle at the bottom of body of water (Davies and Abowei, 2009). Sediment analysis is important in evaluating qualities of total ecosystem of a body of water in addition to water sample analysis 13 practiced for many years because it reflects the long term quality situation independent of the current inputs (Adeyemo et al., 2008).

\section{Materials and Methods}

Sediment samples were collected from five different sampling stations (station 1-Thalachira, station 2- Polachira nadappalam, station 3- Mannathipara, station 4Manalmukku, station 5- near Meenadu Bridge) of Polachira wetland. The sediment samples were collected from April 2013 to march 2014. The sediment samples were taken in polythene bags, and transported to the laboratory. The sediment samples were dried, powdered and sieved for the chemical analysis. The sediment samples collected were analyzed for texture analysis, organic carbon and chlorophyll pigment (chlorophyll a, b and c). Sediment texture analysis was done by mechanical sieving and pipette analysis described by Krumdein and Pettijohn (1938) and Sheppard's nomenclature (1954). The sedimentary pigments are determined by the method of Stickland and Parsons (1977). Sediment organic carbon content was determined by the chromic acid oxidation method suggested by El Wakeel and Riley (1957).

\section{Results and Discussion}

Sediment assessment has importance in determining the contamination and toxicity of particular wetlands. The mean values of different parameters in Polachira wetland in different seasons are shown in table 1.

\section{Texture analysis}

Soil texture refers to the proportion of the soil "separates" that make up the mineral component of soil. These separates are called sand, silt, and clay.

The monthly percentage of sand (fig 1) ranged from $48.06 \%$ during monsoon in 2013 at station III to $82.33 \%$ during post monsoon in 2013 at station I. The monthly analysis on the texture of sediment samples showed $14.31 \%$ to $42.64 \%$ of clay (fig 2). The higher percentage of clay was observed during the month of post monsoon in 2013 at station I and 


\section{International Journal of Science and Research (IJSR) \\ ISSN (Online): 2319-7064}

Index Copernicus Value (2013): 6.14 | Impact Factor (2014): 5.611

lower percentage of clay was observed during the month of monsoon in 2013 at station III. The monthly percentage of silt (fig 3) ranged from 1.31\% during monsoon in 2013 to $27.24 \%$ during pre monsoon in 2014. Station I recorded lower percentage of silt and station II recorded higher percentage of silt.

The textural properties of the sediment revealed that sandy texture dominated all stations throughout the period of study. Sand-sized particles commonly have lower cation exchange and water-holding capacities and higher permeability and porosity (Stolt et al., 2000) than finertextured soils.

\section{Organic carbon}

Soil organic matter (SOM) is the key component that determines soil Water Holding Capacity (WHC). More the SOM content more is the WHC of the soil (Vengadaramana A, 2012). Soil organic carbon (SOC) plays an important role as a source of plant nutrients and in maintaining the soil integrity (Solanki and Chavda, 2012). The month wise data of sediment organic carbon ranged from $73.5 \mathrm{mg} / \mathrm{g}$ to $9.6 \mathrm{mg} / \mathrm{g}$ during august 2013 at station III and January 2014 at station IV respectively.

The decomposition of the organic matter releases total organic carbon into the water which finally accumulates in the sediments and high organic carbon is an organic pollutant (Davies and Abowei, 2009). The high organic carbon contents observed in the monsoon season may due to the deposition of terrestrial organic matter from the excessive land runoff, settling of material and decay of vegetation which is in agreement with value obtained for Paravur-Kappil backwater (Santhosh, 2002).

\section{Chlorophyll Pigments}

\subsection{Chlorophyll a (Chl.a)}

Chlorophyll a (Chl.a) is one of the dominant pigments of phytoplankton and is a useful parameter in analyzing phytoplankton density. The monthly data on Chl.a varied from $0.09 \mathrm{mg} / 1$ during may 2013 at station I to $9.6 \mathrm{mg} / \mathrm{l}$ during june 2013 at station IV. The high value of Chl.a in the monsoon period may be due to the accumulation of sedimentary pigments carried by the rain water runoff and increased plankton growth. The lower value of Chl. a may be as a result of decomposition of algae.

\subsection{Chlorophyll b(Chl.b)}

Chlorophyll $\mathrm{b}$ is a form of chlorophyll. Chlorophyll b helps in photosynthesis by absorbing light energy. Chl.b is a yellowish green pigment having empirical formula $\mathrm{C}_{55} \mathrm{H}_{70} \mathrm{O}_{6} \mathrm{~N}_{4} \mathrm{Mg}$. The month wise distribution of Chl.b varied from $6.89 \mathrm{mg} / 1$ to $0.01 \mathrm{mg} / \mathrm{l}$. The higher value was recorded in the month of February at station $\mathrm{V}$ and lower value was observed in the month of January at station IV $\& V$. The increased Chl.b in the month of February may be due to the increased presence of chlorophytes.

\subsection{Chlorophyll c(Chl.c)}

Chlorophyll c (Chl.c) present in brown algae, diatoms, and Flagellates. Productivity of an ecosystem can be evaluated by studying Chl.c content in the ecosystem. The higher value of Chl.c $(8.39 \mathrm{mg} / \mathrm{l})$ was recorded in the month of February 2013 at station $\mathrm{V}$ and lower value $(0.04 \mathrm{mg} / \mathrm{l})$ was recorded in the month of January 2014 at station I. The increased Chl.c in the month of February may be due to the presence of diatoms and dinoflagellates.

\section{Conclusion}

The studies revealed that the sediment of Polachira wetland contains high range of organic carbon. Chlorophyll pigment values also fluctuated because of the presence and absence of phytoplanktons. Moreover, the results manifested the need and prime necessity to restore the physical, chemical and biological integrity with viable and rigorous restoration and management strategies in order to maintain, preserve, conserve and to avert the ecological imbalance and disturbance in hydro-geo-chemical and hydro-biological cycles, which adversely affect the food chain and food web of the significant wetland ecosystem.

\section{Acknowledgment}

I am sincerely grateful to all teachers in the department of Zoology, M. G. College, Trivandrum and Dr. Ajit Kumar. K.G (HOD, Department of Botany, M. G. College, Trivandrum).

\section{References}

[1] Adeyemo, O. K., Adedokun, O. A., Yusuf, R. K., Adeleye, E. A. 2008. Seasonal changes in physicochemical parameters and nutrient load of river sediment in Ibadan city, Nigeria. GlobalNEST Journal.10(3): 326- 336.

[2] Chapman, D. 1996. Water Quality Assessments. A Guide to the Use of Biota, Sediments and Water in Environmental Monitoring.Second Edition. Published on behalf of UNESCO, WHO, and UNEP. Chapman and Hall, London

[3] Davies, O. A., Abowei, J. F. N. 2009. Sediment quality of lower reaches of Okpoka Creek, NigerDelta, Nigeria. Eur J of Sci Res,26(3): 437 - 442.

[4] El Wakeel, S. K., Riley, J. P. 1957. Organic carbon in marine muds. J.Explor. Mer., 22: 180-183.

[5] Krumbein, E. C., Pettijohn, F. J. 1938. Manual of Sedimentary Petrography. Appleton Century Crofts. Inc., New York. Pp 549.

[6] Pandit, A. K. 1993. Dal lake ecosystem in Kashmir, Himalaya.Eco.poll.Ind. lak.Res.pp131-202.(eds)P. C Mishra and R K Trivedy. Ashish Publishing House. New Delhi.

[7] Santhosh, S. 2002. Hydrgeochemistry of ParavurKappil backwaters with special reference on phytoplankton. Ph.D Thesis, Dept. of Environmental Sciences, University of Kerala 


\section{International Journal of Science and Research (IJSR) \\ ISSN (Online): 2319-7064 \\ Index Copernicus Value (2013): 6.14 | Impact Factor (2014): 5.611}

[8] Shepard, F. P .1954. Nomenclature based on sand- siltclay- ratios. Jour. Sed. Petrol. 24: 151-158.

[9] Solanki, H. A., Chavda, N.H. 2012. Physico-Chemical Analysis With Reference To Seasonal Changes In Soils Of Victoria Park Reserve Forest, Bhavnagar (Gujarat), Life Sciences Leaflets, Vol.8, 62-68.

[10] Stolt, M. H., Genthner,M. H., Daniels, W.L., Groover, V. A., Nagle,S., Haering, K. C. 2000.Comparison of soil and other environmental conditions in constructed and adjacent palustrine reference wetlands. Wetlands 20: 671-683.
[11] Strickland, J. D. H.,Parsons ,T. R. 1977. A practical handbook of sea water analysis. Fish. Res. Board Can. Bull., (2 ${ }^{\text {nd }}$ edn), ottawa. pp 167.

[12] Vengadaramana, A ., Jashothan, P. .T J. 2012 .Effect of organic fertilizers on the water holding capacity of soil in different terrains of Jaffna peninsula in Sri Lanka, Scholars Research Library, J. Nat. Prod. Plant Resour., Vol. 2 (4), 500-503.

[13] Whigham, D. F. 1999. Ecological issues related to wetland preservation, restoration, creation and assessment, The Science of the Total Environment 240 (1999), pp. 31-40.

Fig 1.showing variation in sand content

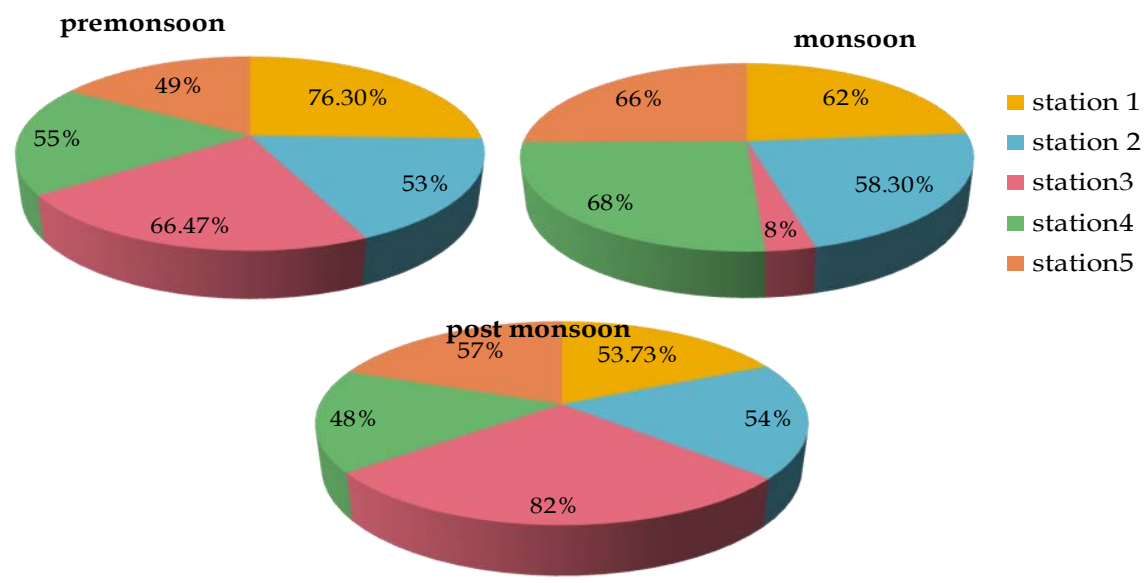

Fig 2.showing variation in clay content
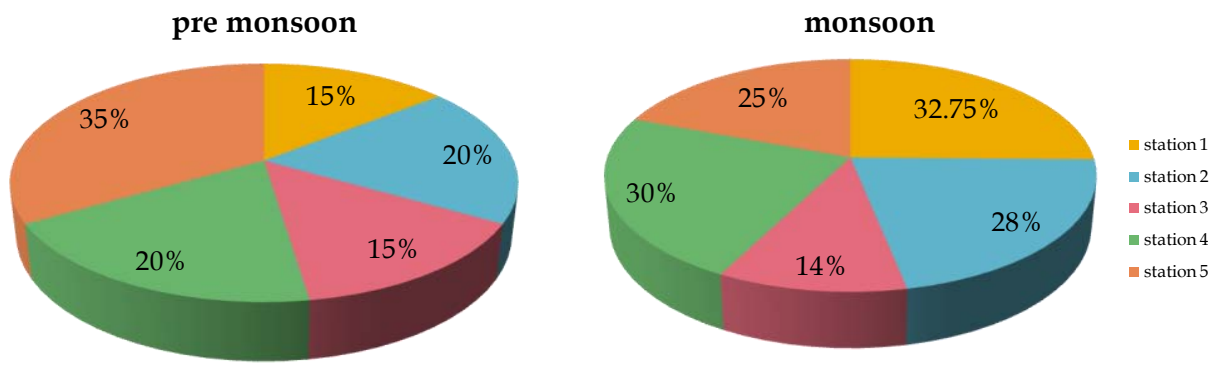

post monsoon

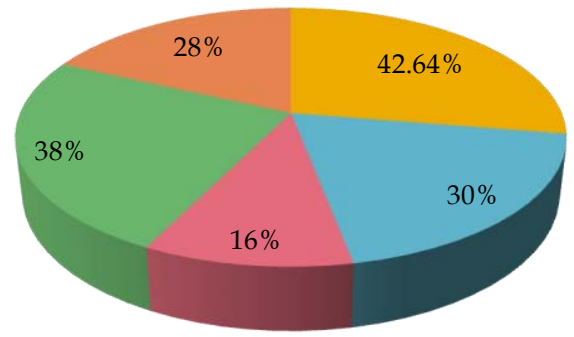

Volume 5 Issue 2, February 2016 


\section{International Journal of Science and Research (IJSR) \\ ISSN (Online): 2319-7064}

Index Copernicus Value (2013): 6.14 | Impact Factor (2014): 5.611

\section{Fig 3.showing variation in silt content}

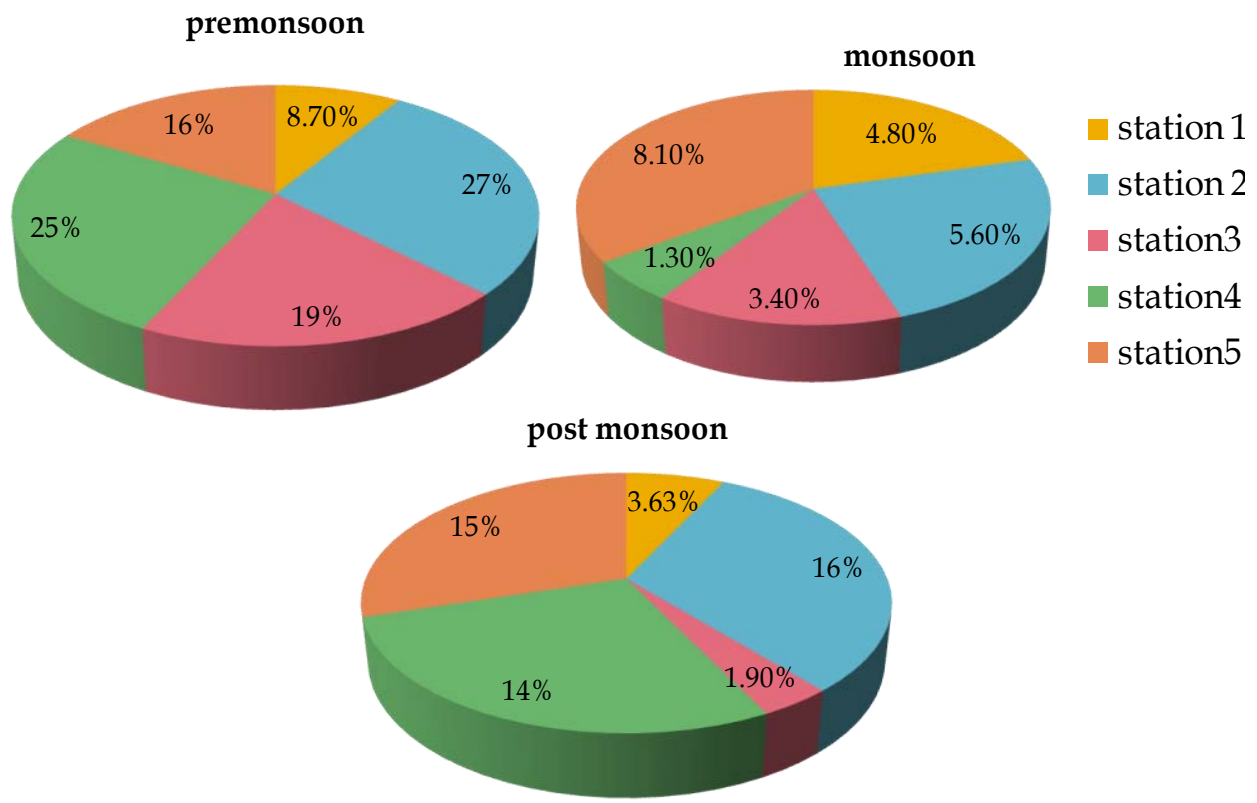

Table 1: The mean value of different parameters in Polachira wetland in different seasons

\begin{tabular}{|c|c|c|c|c|c|}
\hline & Station 1 & Station 2 & Station 3 & Station 4 & Station 5 \\
\hline \multicolumn{6}{|c|}{ Mean value of organic carbon } \\
\hline $\begin{array}{l}\text { Premonsoon } \\
\text { Monsoon }\end{array}$ & $\begin{array}{c}13.35 \\
31.8\end{array}$ & $\begin{array}{l}16.2 \\
26.55\end{array}$ & $\begin{array}{c}13.98 \\
56.1\end{array}$ & $\begin{array}{c}12.45 \\
21.6\end{array}$ & $\begin{array}{l}11.35 \\
20.08\end{array}$ \\
\hline Postmonsoon & 27.6 & 27.2 & 55.45 & 29.05 & 41.28 \\
\hline \multicolumn{6}{|c|}{ Mean value of Chl $a^{*}$} \\
\hline Premonsoon & 1.65 & 1.61 & 1.17 & 1.27 & 3.1 \\
\hline Monsoon & 1.87 & 2.06 & 1.53 & 1.77 & 4.04 \\
\hline Postmonsoon & 0.94 & 0.65 & 0.66 & 0.62 & 0.98 \\
\hline \multicolumn{6}{|c|}{ Mean value of Chl $b^{*}$} \\
\hline Premonsoon & 2.02 & 0.34 & 0.27 & 0.8 & 0.69 \\
\hline Monsoon & 0.27 & 0.36 & 0.22 & 0.32 & 1.27 \\
\hline Postmonsoon & 0.43 & 0.29 & 0.3 & 0.4 & 0.24 \\
\hline \multicolumn{6}{|c|}{ Mean value of Chl $c^{*}$} \\
\hline Premonsoon & 0.66 & 1.42 & 1.01 & 0.93 & 2.75 \\
\hline Monsoon & 1.42 & 1.72 & 1.3 & 1.65 & 2.32 \\
\hline Postmonsoon & 0.53 & 0.48 & 0.46 & 0.46 & 0.51 \\
\hline
\end{tabular}

* Chl.a-chlorophyll a, Chl.b-chlorophyll b, Chl.c-chlorophyll c. 